\title{
MANAGEMENT OF CLEFT LIP AND PALATE (Literature Review)
}

\author{
Putu Sulistiawati Dewi \\ Department of Oral and Maxillofacial Surgery \\ Faculty of Dentistry, University of Mahasaraswati, Denpasar Bali \\ Emai : p_liez@yahoo.com
}

\begin{abstract}
Cleft lip and cleft palate (orofacial cleft) are facial and oral malformations that occur very early in pregnancy. A cleft lip and cleft palate, known technically as an orofacial cleft, is actually a group of various conditions that involve a "cleft" on the patient's face. Clefting results when there is not enough tissue in the mouth or lip area, and the tissue that is available does not join together properly. Cleft lip and cleft palate can occur on one or both sides of the mouth. Because the lip and the palate develop separately, it is possible to have a cleft lip without a cleft palate, a cleft palate without a cleft lip, or both together. Children with a cleft lip with or without a cleft palate or a cleft palate alone often have problems with feeding and speaking clearly and can have ear infections. They also might have hearing problems and problems with their teeth. Cleft lip with or without cleft palate, can be diagnosed during pregnancy by a routine ultrasound. They can also be diagnosed after the baby is born, especially cleft palate. Treatment with orofacial clefts can vary depending on the severity of the cleft; the child's age and needs; and the presence of associated syndromes or other birth defects, or both.
\end{abstract}

Keywords : cleft lip, cleft palate, orofacial cleft

\section{PENDAHULUAN}

Celah bibir dan palatum adalah salah satu bentuk kelainan bawaan yang paling sering dijumpai. Celah orofasial berupa celah bibir dengan atau tanpa celah palatum dan celah palatum yang terjadi tanpa disertai celah bibir dapat terjadi pada 1 diantara 500 hingga 1000 bayi yang lahir di dunia. ${ }^{1}$

Efek pada kemampuan berbicara, pendengaran, penampilan, dan psikologis dapat mengarah pada kondisi kesehatan dan integrasi sosial yang buruk pada penderita. Biasanya, anak dengan kelainan ini membutuhkan perawatan multidisipliner sejak lahir hingga dewasa dan memiliki morbiditas dan mortalitas yang lebih tinggi dibandingkan dengan individu tanpa kelainan bawaan ini. ${ }^{1}$

Selama bertahun-tahun, berbagai teknik telah dikembangkan untuk memperbaiki deformitas celah bibir atau celah bibir yang disertai celah palatum. Pemahaman terhadap manajemen deformitas celah bibir maupun palatum membutuhkan pengetahuan mendasar mengenai proses embriologi wajah dan klasifikasi kelainan celah bibir dan palatum. Kelainan struktural yang menyertai mempengaruhi manajemen pasien dan keberhasilan prosedur perawatan yang dilakukan. Sekalipun kemudahan akses terhadap perawatan telah meningkat dalam beberapa tahun terakhir, pencegahan tetap menjadi tujuan utama perawatan kelainan bawaan ini. ${ }^{3}$

\section{PEMBAHASAN}

Celah bibir dan palatum adalah salah satu kelainan bawaan yang paling sering dijumpai dan disebabkan oleh gangguan proses tumbuh kembang selama bayi ada di dalam kandungan dan ditandai dengan adanya ketidaksempurnaan pembentukan bibir bagian atas atau terdapatnya saluran abnormal yang melalui langit-langit mulut dan menuju saluran udara di hidung. Celah bibir dan palatum dapat terjadi sendirisendiri maupun terjadi bersamaan. Sekalipun keberadaan celah bibir dan palatum tidak terlalu membahayakan jiwa penderita, kondisi ini menyebabkan gangguan atau kerusakan pada wajah (khususnya bila tidak diberi perawatan apapun), gangguan proses komunikasi, dan mengakibatkan keterbatasan perkembangan sosial individu penderita. ${ }^{2}$

\section{Embriologi dan Etiologi Celah Bibir dan Palatum}

Perkembangan embriologi wajah merupakan suatu proses yang kompleks dan terjadi pada tahap fetal awal. Diperlukan koordinasi yang baik mulai dari migrasi sel, pertumbuhan, diferensiasi, dan apoptosis. Neural crest cell, yang berasal dari lipatan syaraf (neural folds) berkontribusi dan bermigrasi melalui jaringan mesenkimal ke area kraniofasial yang sedang mengalami proses perkembangan pada minggu ke-4 intrauterin. Sel ini kemudian berpartisipasi dalam pembentukan prosesus frontonasalis, prosesus maksilaris, dan prosesus mandibularis yang mengelilingi rongga mulut ${ }^{2}$.

Perkembangan wajah diawali pada bagian tengah prosesus frontonasalis yang berkembang di sekitar otak yang juga sedang mengalami proses perkembangan. Kedua prosesus maksilaris berkembang ke anterior di antara vesikel optik dan primitive stomodeum sementara kedua prosesus mandibularis berkembang di bawah stomodeum. Penggabungan antara prosesus maksilaris dan prosesus frontonasal menghasilkan adalnya pembentukan premaksila yang kemudian menjadi tempat berkembangnya gigi-gigi insisivus. Struktur fasial mulai bisa dikenali pada 
minggu ke-5 hingga ke-6 intrauterin. Pada akhir minggu ke- 6 , terjadi penggabungan prosesus nasalis medialis dengan prosesus maksilaris yang kemudian diikuti dengan pembentukan bibir atas dan palatum primer. Sesaat sebelum proses ini selesai, pembelahan sel pada prosesus nasalis lateralis mengalami puncaknya sehingga hal ini menyebabkan proses tumbuh kembang pada area ini sangat rentan terhadap gangguan teratogenik dan berbagai gangguan tumbuh kembang lain sehingga kondisi ini dapat menyebabkan kegagalan pada mekanisme penyatuan prosesus kiri dan kanan. Tanda pertama dari pertumbuhan dan perkembangan palatum sekunder terjadi pada minggu ke-6 intrauterin yang diawali dari perkembangan prosesus maksilaris yang mengalami pertumbuhan secara vertikal di sekitar lidah yang sedang mengalami proses pembentukan. Pada minggu ke-7, terjadi fusi antara prosesus palatina kiri dan kanan yang kemudian diikuti proses degenerasi yang memungkinkan jaringan mesenkimal berkembang menutupi area ini. Jaringan mesenkimal di palatal kemudian berdiferensiasi menjadi tulang dan otot yang masing-masing kemudian membentuk palatum keras dan lunak. Selain terjadi fusi pada garis tengah (midline), palatum sekunder bergabung dengan palatum primer dan septum nasalis. Proses penggabungan tersebut terjadi dan selesai pada minggu ke-10 intrauterin. Perkembangan palatum sekunder pada mamalia menyebabkan rongga oronasal terbagi menjadi rongga mulut dan rongga hidung sehingga memungkinkan proses pengunyahan dan respirasi berlangsung secara simultan ${ }^{2}$.

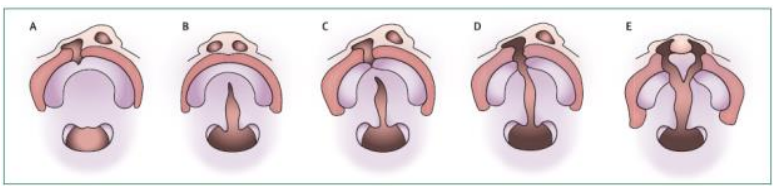

Gambar 1 : Celah orofasial non-sindromik: (A) celah bibir dan alveolus, (B) celah palatum, (C) celah bibir dan palatum unilateral dan tidak sempurna (incomplete unilateral cleft lip and palate), (D) celah bibir dan palatum unilateral dan sempurna (complete unilateral cleft lip and palate), (E) celah bibir dan palatum bilateral dan sempurna (complete bilateral cleft lip and palate). ${ }^{2}$

Menurut Mooney \& Siegel (2002), penyebab celah orofasial terbagi menjadi 2, yaitu faktor internal (genetik) dan faktor eksternal. Kondisi genetik yang menyebabkan celah orofasial terbagi menjadi kondisi genetik sindromik dan non-sindromik. Kondisi genetik sindromik dikaitkan dengan keberadaan sindrom tertentu sementara keadaan non-sindromik dikaitkan dengan faktor keturunan. Sementara itu faktor lingkungan penyebab celah orofasial antara lain adalah sebagai berikut:

1. Faktor lingkungan (medikasi, racun)

2. Faktor maternal (defisiensi vitamin, gangguan hormon)

3. Faktor intrauterine

Abnormalitas Struktural dari Celah Bibir dan Palatum
Komponen anatomi deformitas celah:

1. Bibir

Terdapat diskontinuitas bibir termasuk vermilion dan kulit. Terjadi pemisahan otot orbicularis oris dengan perlekatan yang abnormal pada kulit, crus lateral kartilago alaris, dan tulang sekitar.

2. Hidung

Deformitas hidung terjadi minimal atau tidak ada pada celah bibir tidak sempurna dengan anatomi otot orbicularis oris yang intak. Deformitas nasal 'formefruste' terjadi pada bibir yang intak. Pada kasus ini deformitas nasal terkait dengan insersi abnormal serat otot facial.

3. Alveolus

Celah pada alveolus biasanya terjadi diantara incisivus lateral dan caninus kemudian meluas secara obliq ke arah foramen incisivus. Besar celah alveolus bervariasi mulai dari takik pada gingiva hingga celah sempurna. Akan tetapi, manifestasi yang terlihat tidak berkorelasi dengan besarnya pemisahan tulang di bawahnya.

4. Palatum primer

Celah pada palatum primer meluas ke posterior ke foramen incisivum, mengakibatkan defisiensi pada bagian dasar rongga hidung. Lengkung alveolar pada sisi yang bercelah berotasi ke mesiopalatal dan pada sisi yang tidak bercelah berotasi keluar karena perlekatan otot wajah yang abnormal.

5. Palatum sekunder

Palatum sekunder meluas ke posterior dari foramen incisivum ke uvula, terdiri dari palatum keras dan palatum lunak.

6. Maksila

Maksila pada sisi yang terkena terdefisiensi pada dimensi vertikal dan anteroposterior.

7. Mandibula

Dimensi mandibula pada pasien dengan celah palatum dapat berukuran lebih kecil.

8. Abnormalitas lain

Anatomi abnormal otot palatum lunak, terutama pada tensor velipalatini dipercaya dapat mengganggu jalan udara pada telinga tengah karena kegagalan pembukaan tuba eustachius saat menelan, menguap, dan pergerakan faring lainnya.

\section{TATA LAKSANA PERAWATAN}

\section{Perawatan Operasi Celah Bibir dan Palatum}

Tujuan dari perawatan bedah pada celah:

1. Memperbaiki penampilan dan kesimetrian wajah

2. Pengucapan normal

3. Oklusi normal

4. Pendengaran normal

Komponen perawatan deformitas celah:

1. Koreksi geometri permukaan jaringan

2. Mengembalikan struktur dan fungsi anatomi

3. Menyesuaikan pertumbuhan dan perkembangan rahang dan gigi

4. Mengembangkan pengucapan dan pendengaran normal 
Masih terdapat kontroversi mengenai waktu yang terbaik untuk melakukan operasi pada celah palatum. Beberapa peneliti mengemukakan bahwa perbaikan yang awal pada palatum berkaitan dengan kemampuan pengucapan yang lebih baik tetapi dapat menghasilkan deformitas dentofacial. Randall dan McComb juga Lehman melaporkan bahwa anak yang dioperasi pada umur awal memiliki pengucapan yang lebih baik dan lebih sedikit memerlukan faringoplasti sekunder daripada anak yang operasinya dilakukan di atas 12 bulan. ${ }^{3}$

\section{Prosedur Operasi Celah Bibir dan Palatum}

\section{Operasi Primer}

Tujuan dari perbaikan primer adalah untuk menutup celah, memperbaiki simetri atau dimensi dari bibir akibat deformitas geometri dan mengembalikan struktur dan fungsi anatomi dari jaringan yang telibat.

Sebelum operasi perlu diperhatikan syarat untuk dilakukan operasi, yaitu "Rule of 10", terdiri dari kadar hemoglobin 10, kadar hematokrit minimal 30\%, berat minimal 10 pounds, dan usia minimal 10 minggu.

\section{a. Labioplasti}

Teknik yang populer digunakan untuk perbaikan bibir adalah:

- Penutupan garis lurus (operasi veau III)

- Adaptasi dari perbaikan celah bibir unilateral Tennison

- Perbaikan celah komplit dan inkomplit bilateral oleh Millard

- Lainnya: teknik Skoog, metode Manchester, Barsky (veau II), flap primer Abbe
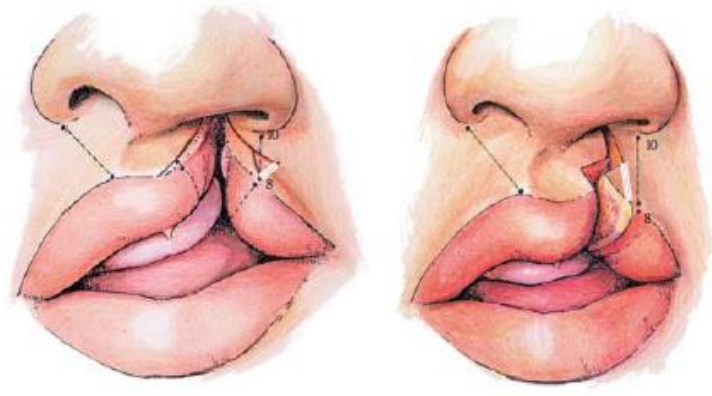

Tennison-Randall's Procedure ${ }^{8}$
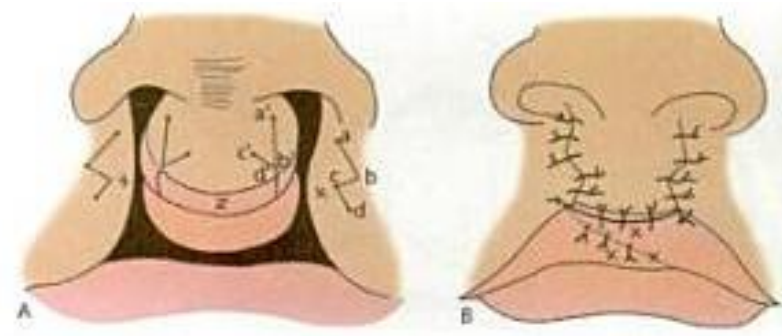

Gambar 2. Perbaikan celah bibir bilateral dengan Tennison's procedure.

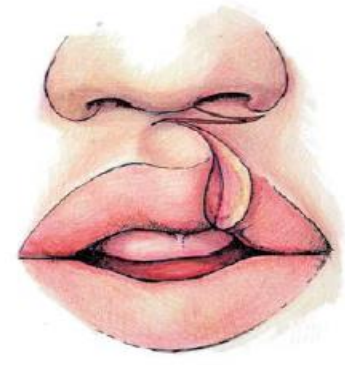

Millard Procedure
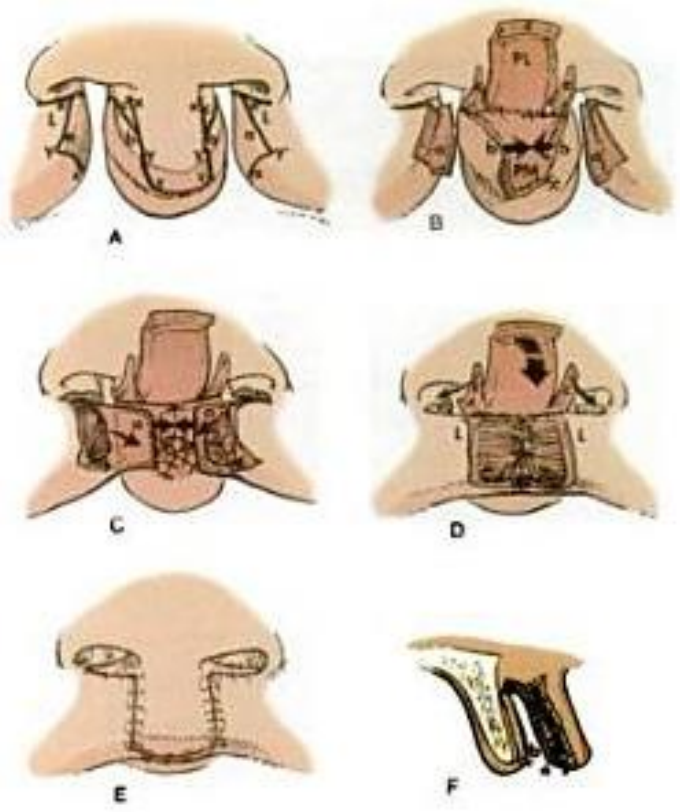

Fig. 22, 18. Black's bilateral repais.

Gambar 3. Perbaikan celah bibir bilateral dengan Black's bilateral repair.

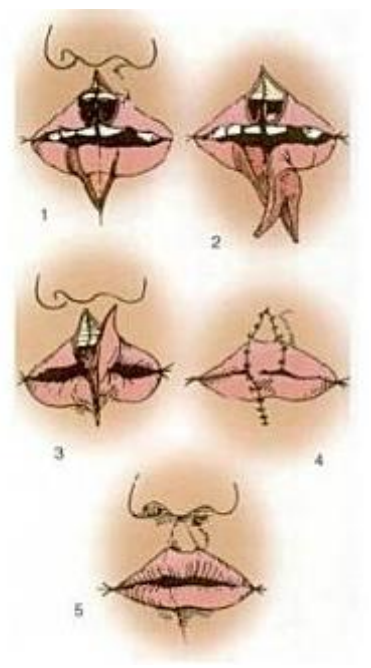

Gambar 4. Abbe's Flap ${ }^{8}$. 


\section{b. Palatoplasti ${ }^{5}$}

Teknik yang dilakukan untuk perbaikan palatal:

- Operasi Von Langenbeck

- Palatoplasti pushback V-Y (Kilner \& Wardill)

- Palatoplasti dua flap

- Furlow double opposing Z-plasty

\section{Operasi Von Langenbeck}
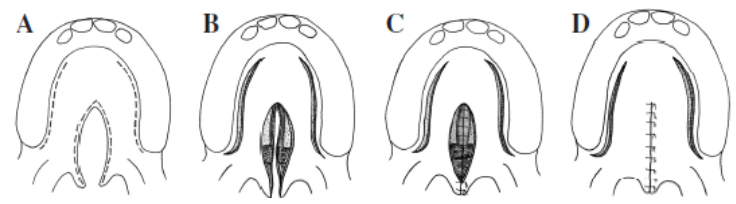

Gambar 5. Palatoplasti Vn Langenbeck A) Penandaan desain flap. (B) Flap mukperiosteal bipedikle dielevasikan dari insisi lateral ke tepi celah. (C) Penutupan layer nasal mukoperiosteal. (D) Penutupan flap ral mukperiosteal

\section{Palatoplasti pushback V-Y (Kilner \& Wardill)}
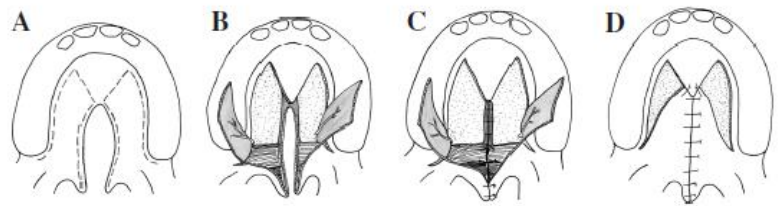

Gambar 6. Veau-Wardill-Kilner atau palatoplasti VY pushback. (A) Penandaan area insisi. (B) Flap oral mukperisteal diangkat dengan tetap menjaga pembuluh darah palatina besar pada kedua sisi. (C) Retroposisi dan perbaikan dari otot levator veli palatini (intravelar veloplasti) setelah menyelesaikan perbaikan mukoperosteal. (D) Hasil akhir setelah penutupan flap oral mukoperiosteal.

3. Palatoplasti dua flap
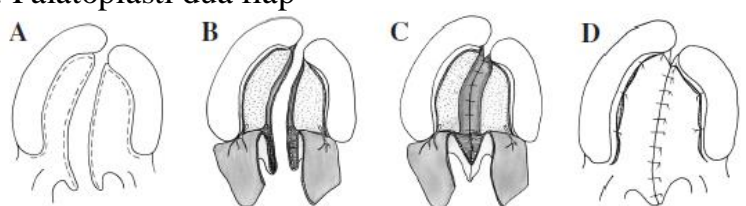

Gambar 7. Palatoplasti dua flap. (A) Penandaan desain flap. (B) Elevasi dari dua flap mukperosteal dari permukaan oral. Pembuluh darah palatina besar dari kedua sisi tetap dijaga. (C) Retroposisi dan perbaikan dari otot levator veli palatini (intravelar veloplasti) setelah menyelesaikan perbaikan mukoperosteal. (D) Hasil akhir setelah penutupan flap oral mukoperiosteal.

\section{Furlow double opposing Z-plasty}
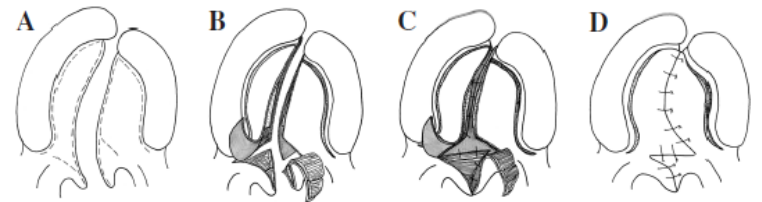

Gambar 8. Furlow double opposing z-palatoplasti. (A) Penandaan dari insisi z-plasti dan insisi kendur. Pada celah palatum yang beasr, insisi kendur dibuat di sebelah anterior dari tepi celah sebagai palatoplasti dua flap. (B) Elevasi dari flap oral. Layer oral terdiri dari flap muskulmukosal pada sisi kiri dan hanya flap mukosa di sisi kanan. Otot diangkat sebagai dasar flap posterior. Insisi yang mirip juga ditandai berkebalikan dengan layer nasal. (D) Flap nasal muskulomukosal pada sisi kanan dibawa melewati celah. (D) Hasil tampak akhir layer oral yang ditutup oleh z-plasti.

\section{Operasi Sekunder}

Perawatan pada anak-anak dengan celah bibir atau celah palatum bervariasi. Tidak ada dua anak yang memiliki kebutuhan yang sama. Beberapa mungkin hanya membutuhkan dua operasi, dan anak lainnya mungkin butuh lebih dari dua operasi. Tujuan dari perawatan adalah untuk mencapai penapilan sebaik mungkin, cara bicara yang terbaik dan gigi terbaik dan tersehat pula.

Dibawah ini merupakan beberapa operasi tambahan yang dapat direkomendasikan untuk anak:

\section{a. Penutupan Fistula}

Penutupan fistula diikuti perbaikan celah palatal seringkali dilakukan lebih awal bila dirasa fistula tersebut dapat menyebabkan masalah fungsional bicara, menelan atau baliknya makanan yang sudah dicerna melalui nasal. Adanya fistula tidak memerlukan penutupan bila tidak terdapat atau prediksi masalah fungsional berkaitan dengan fistula.

\section{b. Operasi untuk Bicara}

Faringoplasti didesain untuk mengurangi dimensi dari pembukaan velofaring untuk memfasilitasi atau sekedar meningkatkan resistansi saluran nafas untuk meminimalkan lolosnya udara nasal. Secara umum diklasifikasikan sebagai prosedur dinamis (contoh: ortikokea faringoplasti) yang didesain untuk memobilisasi otot palatofaring pada pilar tonsil posterior dan melekatkan mereka pada dinding faring posterior. Prosedur pasif hanya mempersempit pembukaan velofaring atau augmentasi dinding faring posterior menggunakan bahan implant.

\section{c. Revisi bibir}

Operasi tambahan pada bibir dapat disarankan untuk meningkatkan fungsi atau penampilan dari bibir. Luka pada kulit antara hidung dan bibir harus halus dan rata. Penampilan dari bibir harus sesimetris atau seseimbang mungkin pada kedua sisi. Tujuan dari operasi ini untuk menjadikan bibir tampak senormal mungkin.

d. Operasi graft tulang celah alvelar

Celah alveolar adalah celah atau pembukaan pada tulang rahang atas di bawah gusi. Tulang dibutuhkan pada rahang atas di bawah gusi agar gigi-gigi permanen dapat erupsi, akarnya berkembang dan sehat. Tulang pada rahang atas juga mendukung dasar dari hidung. Perasi ini sering dilakukan ketika usia anak 8 hingga 10 tahun.

e. Dynamic Sphincter Pharyngoplasty atau palatoplasti

Dalam persentase kecil, anak-anak dengan celah palatum memiliki kesulitan bicara. Terkadang terlalu banyak udara yang masuk melalui hidung 
menyebabkan suara hipernasal. Seorang patologis bicara dapat mengevaluasi cara bicara anak dan menentukan apakah mereka tidak dapat berbicara dengan baik karena tidak dapat menutup ruang antara palatum lunak dan bagian belakang tenggorokan (VPI atau velopharyngeal incompetence atau insufficiency). Operasi tambahan dapat mengkoreksi hal ini. Operasi dynamic sphincter pharingoplasty (DSP) mengambil 2 flap dari sisi-sisi tenggorokan untuk membuat cincin jaringan sehingga jarak velfaringeal mengecil.

\section{f. Rhinoplasti}

Usia sebelum sekolah juga waktu yang umum bagi rang tua untuk meminta prosedur korektif kedua untuk asimetri hidung dengan prosedur rhinoplasti. Rhinoplasti kedua pada saat mendekati akhir masa pertumbuhan umum dilakukan. Apabila direncanakan operasi ortognati, prosedur ortognatik dapat mengembalikan simetri dan keseimbangan astetis wajah, terutama dasar tulang hidung. Prosedur ini dapat dikombinasikan dengan operasi ortognatik untuk meminimalkan jumlah operasi intervensi.

g. Operasi Ortognatik

Anak-anak yang memiliki celah bibir dan palatum dan menjalani perawatan kemungkinan dapat mengahasilkan wajah yang tidak seimbang. Gigigigi mereka mungkin tidak pas secara tepat (maloklusi). Sebagai tambahan, akibat dari gigitan yang tidak tepat, bibir atas bisa tidak terproyeksikan dengan benar. Operasi orthgnatik menunjuk pada operasi yang merubah posisi rahang atas dan atau rahang bawah, sehingga gigigigi dapat tepat berada pada tempatnya dan memberikan keseimbangan pada wajah. Biasanya operasi ini ditunda hingga anak telah beranjak remaja dan wajah dan rahang sudah tumbuh sempurna.

\section{SIMPULAN DAN SARAN}

1. Keberadaan celah bibir dan palatum meskipun tidak membahayakan jiwa penderita, namun bila tidak dilakukan perawatan dapat menyebabkan gangguan atau kerusakan pada wajah, gangguan proses komunikasi, dan mengakibatkan keterbatasan perkembangan sosial individu.
2. Celah orofasial dapat disebabkan karena faktor internal (genetik) dan faktor eksternal. Kondisi genetik terbagi menjadi kondisi genetik sindromik dan non-sindromik. Sementara itu contoh faktor eksternal antara lain adalah faktor lingkungan, faktor maternal dan faktor intrauterin.

3. Prosedur operasi harus dilakukan pada waktu yang tepat. Koreksi pada waktu yang tidak tepat dapat menyebabkan hambatan pada pertumbuhan dan perkembangan orofasial.

\section{DAFTAR PUSTAKA}

1. Hesein E., Aalst JV., Aksoy A. Smile Dental Journal. 2012. Cleft Lip and Palate : The Multidisciplinary Management, vol 7: issue 4.

2. Allori AC., Maera JG., Mulliken JB., Shusterman S. The Cleft Palate-Craniofacial Journal. 2015. Classification of Cleft Lip/Palate : Then and Now : PubMed.54(2).

3. Precious DS., Goodday RH., Morrison AD., Davis BR. Clinical Practice. 2001.Cleft Lip and Palate : A Review for Dentists: 67(11).

4. Riden, K. 1998. Oral \& Maxillofacial Surgery text book. Page 71.

5. Peterson LJ, Ellis E, Hupp JR. 2005 . Contemporary Oral and Maxillofacial Surgery Fourth Edition Text Book- Management of Patients with Orofacial Clefts Chapter 27 : Page 633.

6. Sianita P.P, Alawiyah T. 2011. Kelaianan Celah Bibir Serta Langit-langit Dan Permasalahannya Dalam Kaitan Dengan Interaksi Sosial Dan Perilaku. Jurnal Ilmiah dan Teknologi Kedokteran Gigi FKG UPDM (B). 8(2) :42-46

7. Dyleski RA, Crockett DM. 2006. Cleft lip and palate: evaluation and treatment of primary deformity. Dalam: Bailey BJ, Johnson JT, Newlands SD, editor (penyunting). Head and neck surgery otolaryngology. Edisi ke-4. Philadelphia: Lippincott Williams \& Wilkins. P:1338-54.

8. Hafiz A, Irfandy D, Rahman S, Rahmadona. 2017. Jurnal Kesehtan Andalas. 6(2): 469-477 